\title{
BUDAYA JAWA DALAM DIASPORA: TINJAUAN PADA MASYARAKAT JAWA DI SURINAME
}

\author{
Darmoko \\ University Indonesia \\ pak.darmoko@gmail.com
}

\begin{abstract}
Javanese society and culture has been forged by the situation and condition of the times centuries. Cultural influences from outside, such as the Hindu - Buddhist, Islamic, Chinese, and European, indigenous cultures should lead to "adapt", the acculturation strategy. Local genius to filter incoming external cultural influence of local culture. Javanese culture and society continues to change, whether caused by external and internal factors.

Policy and socio-economic problems caused the population of a particular region should move. Dutch colonial period to independence there has been a migration of people from rural to urban areas of Java, from a rural island to another, and from a village in Indonesia to foreign countries. In new areas of the Javanese form a new community as the Javanese developed overseas and that's where Javanese culture that was once their preserve, coached, and developed, such as the Java community in Jakarta, Deli Serdang - North Sumatra, Sitiyung west Sumatra, Lampung, and Suriname. Java community in this new place coexist and mingle with other tribes and not seldom of those who later married and have children and grandchildren .

In the early days of the country Suriname frequent conflicts between tribes that are in there. Suriname Javanese people often act as peacemaker for the tribes opposing it. Javanese cultural values operate to defuse a tense situation and soften the situation and condition of the nuances of violence. The value of local knowledge of Java can be used as an "heirloom" wherever people are and in what circumstances they experience. The value of local knowledge of Java prioritize a sense of leadership and uphold the principles of equality and harmony and respect. This paper aims to explore the value of indigenous leadership that operates on Java Javanese in Suriname. Results will be achieved this paper determined the value of local knowledge is Java - oriented leadership as a solution for the value of a conflicts in society.
\end{abstract}

Keywords : Java, culture, values, diaspora, Suriname

\section{PENDAHULUAN}

Pembahasan mengenai kebudayaan dan masyarakat Jawa dari berbagai disiplin ilmu dari masa ke masa tiada habis-habisnya. Para sarjana yang mumpuni dalam bidangnya senantiasa berusaha untuk mendiskusikan baik dalam kesempatan sarasehan, seminar, konferensi, kongres, maupun dalam wujud bukubuku terbitan, majalah, koran, dan sebagainya. Khazanah kebudayaan dan masyarakat Jawa secara berkesinambungan memberikan kontribusi yang sangat berarti kepada masyarakat luas, baik di dalam negeri maupun mancanegara. Studi dan apresiasi kebudayaan dan masyarakat Jawa tersebar di seluruh dunia, baik di 
kota-kota benua Asia, Eropa, Australia, maupun Amerika. Hal tersebut sebagai bukti bahwa "jawa" memiliki sifat terbuka, obyektif, luwes, dan akomodatif.

Di dalam kata "jawa” dikandung beberapa makna. Pertama berarti semacam rumput (jawawut), pulau Jawa berarti pulau jawawut (padi, beras). Kedua, kata "jawa" berhubungan dengan nilai moral, misalnya dalam istilah "tidak jawa" berarti tidak mengerti aturan, bodoh, atau dungu dan kata njawani berarti bertutur kata, bersikap, dan berperilaku Jawa. Ketiga, "jawa" berarti bahasa dan kebudayaan yang dimiliki oleh suku bangsa Jawa. Bahasa Jawa itu sendiri menurut Poerbatjaraka tergolong bahasa Austronesia, yaitu bahasa-bahasa yang dipergunakan oleh bermacam-macam bangsa pribumi yang mendiami kepulauan sebelah tenggara benua Asia, perbatasan sebelah utara mulai pulau Formosa ke selatan, perbatasan sebelah barat mulai pulau Madagaskar terus ke timur sampai daratan Amerika Selatan bagian barat (Poerbatjaraka, 1952: v).

Menilik etnis Jawa pada masa kolonial Belanda hingga kemerdekaan, beberapa bagian dari padanya telah mengalami perpindahan, baik dari desa ke kota, dari desa sebuah pulau ke pulau lain, maupun dari sebuah desa di Indonesia ke mancanegara, baik dengan cara spontan, bedhol desa, maupun tenaga kontrak. Di daerah-daerah baru tersebut orang-orang Jawa membentuk komunitas baru sebagai orang Jawa perantauan dan di sanalah berkembang kebudayaan Jawa yang dibawa dan dulu pernah mereka lestarikan, bina, dan kembangkan di desa. Sebagai contoh perpindahan orang-orang Jawa dari desa ke kota, seperti dari sebuah desa di Jawa Tengah-Jawa Timur ke Jakarta; dari desa di Jawa TengahJawa Timur ke luar pulau Jawa, seperti ke Deli Serdang (Sumatra Utara), Sitiyung (Sumatra Barat), dan Lampung; dari desa di Jawa Tengah, Jawa Timur, Jawa Barat ke negara Suriname.

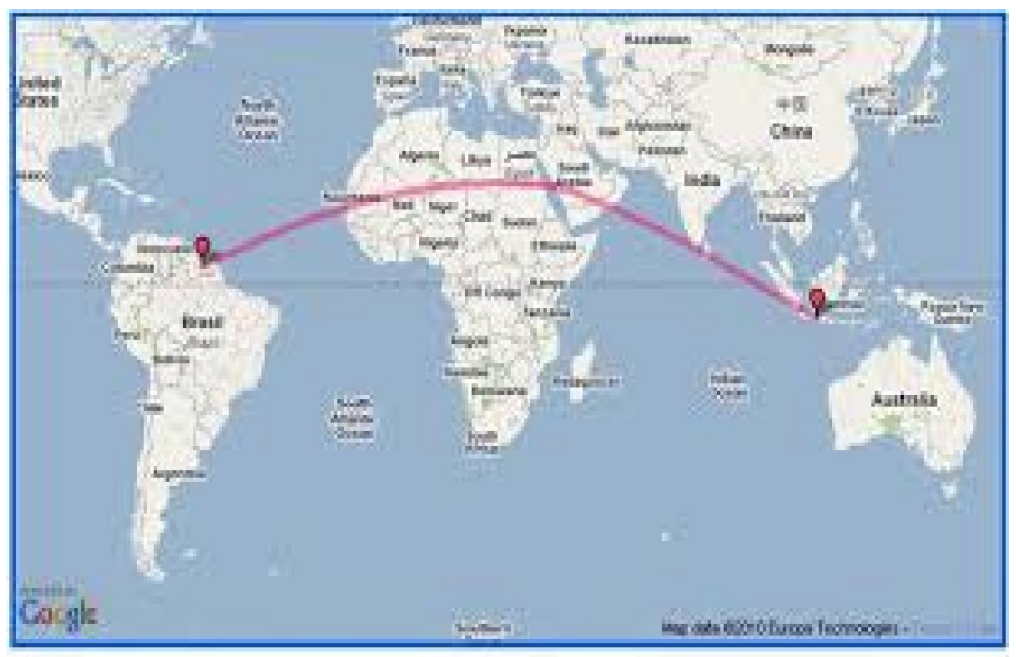

Perpindahan

penduduk dari pulau Jawa ke Suriname http://ustadzaris.co $\underline{m / w p}-$ content/uploads/201 1/01/Petasuriname.jpg

Berdasarkan "Keterangan Dasar Suriname" mengenai "Penduduk Keturunan Jawa di Suriname" (2003: 11), perpindahan sebagian etnis Jawa ke Suriname merupakan dampak berakhirnya sistem perbudakan pada tahun 1863. Pada saat itu banyak tenaga kerja yang meninggalkan pekerjaannya di perkebunan-perkebunan dan beralih ke lapangan kerja lain sesuai dengan keinginan mereka masing-masing. Situasi ini menyebabkan perkebunan yang merupakan salah satu tulang punggung perekonomian Belanda mengalami 
kemerosotan tajam. Pemerintah Belanda kemudian mendatangkan orang Indonesia (Hindia Belanda) untuk memperoleh buruh murah yang akan dipekerjakan di perkebunan-perkebunan. Hampir seluruh buruh kontrak didatangkan dari Jawa Tengah, karena saat itu wilayah ini sudah cukup padat penduduknya dan rawan bencana alam berupa gunung meletus yang mengakibatkan rendahnya tingkat perekonomian masyarakat.

Kelompok imigran Indonesia pertama direkrut oleh "De Nederlandsche Handel Maatschappij” terdiri dari 94 orang yang tiba di Suriname pada tanggal 9 Agustus 1890 untuk diperkerjakan di perkebunan tebu dan perusahaan gula Marrienburg. Kelompok imigran yang kedua terdiri dari 582 orang Jawa didatangkan oleh perusahaan yang sama pada tahun 1894. Sejak 1897 imigran dari Indonesia dikelola langsung oleh pemerintah Hindia Belanda. Imigran dari Indonesia sejak 1890-1939 tercatat 32.956 orang dengan 34 kali pengangkutan. Berdasarkan perjanjian yang ada, para buruh Jawa tersebut memiliki hak untuk kembali ke Indonesia melalui repatriasi bila telah habis masa kontraknya. Pada tahun 1890-1939 tercatat 8.120 orang telah kembali ke tanah air; pada tahun 1947 berjumlah 1.700 orang; dan terakhir pada tahun 1954 berjumlah 1.000 orang. Dengan demikian sebagian besar buruh kontrak yang telah habis masa kontraknya tersebut memilih tinggal di Suriname sebagai pekerja bebas.

Di kemudian hari kejayaan perkebunan tebu mulai merosot, sehingga banyak pekerja Jawa yang beralih profesi sebagai buruh industri, seperti pertambangan bauksit di Moengo, Paranam, dan Biliton. Pada tahun 1975 banyak orang Jawa yang ikut ambil bagian dalam migrasi massal menuju Belanda dari total 150.000 orang meninggalkan Suriname, karena didorong kekhawatiran mereka terhadap kemungkinan terjadinya bencana nasional serta dominasi dan penindasan politis yang dilakukan oleh golongan etnis Creole. Kekhawatiran itu muncul terutama menjelang pemilu Suriname pada tahun 1973, dalam rangka pembentukan pemerintah pertama Suriname merdeka yang diwarnai ketegangan hubungan antar suku.

\section{Permasalahan}

Pada tanggal 25 Februari 1980 di Suriname terjadi kudeta militer dipimpin Desi Bouterse menembak mati tokoh-tokoh oposisi yang sebagian besar keturunan Hindustan dan tahun 1986 terjadi perang saudara (civil war) oleh etnis Maroon melawan Pemerintahan Bouterse tetapi etnis lain juga melawan dan menjadi korban. Maka kejadian ini memicu exodus orang-orang Suriname ke Belanda termasuk etnis Jawa. Orang-orang Jawa dalam hal ini sebagai korban dan tidak turut campur dalam peperangan (konflik) itu. Orang-orang Jawa dalam menghadapi huru-hara ini bersikap netral dan tidak agresif, perasaan sebagai "pendatang rombongan akhir" di Suriname masih terasa pada sikap para tokoh Jawa di Suriname, di samping mental Jawa yang andhap asor (rendah hati): "wong ngalah luhur wekasane" (orang mengalah pada akhirnya tinggi derajatnya) masih cukup terpatri dalam sanubari mereka.

Budaya Jawa (bahasa dan sastra Jawa, kesenian Jawa, religi dan adatistiadat Jawa, organisasi sosial - budaya- politik Jawa, mata pencaharian hidup Jawa, teknologi dan peralatan Jawa, pengetahuan Jawa) yang dibawa dari tanah air Indonesia masih tumbuh dan berkembang dan terpelihara dengan cukup baik 
tetapi dari generasi ke generasi makin rendah kadarnya. Sikap hormatmenghormati, saling menghargai, tepa slira, mawas diri, toleransi, samadsinamadan (saling memperhatikan dan simpati) dan daya-dinayan (saling memberi kekuatan), serta nilai kebersamaan dan kesamaan dalam berkehidupan masih diterapkan masyarakat Jawa di Suriname terutama kalau ada kesripahan selalu luber yang melayat, demikian pula acara bersih desa, pesta-pesta lapangan orang Jawa sangat meriah dan ribuan yang hadir, "bada kupat" dalam rangka lebaran/ Idul Fitri. Nilai-nilai kearifan lokal Jawa tersebut diterapkan juga oleh masyarakat Jawa terhadap suku bangsa yang lain di Suriname, namun tidak seintensif terhadap lingkungan Jawa. Permasalahan yang dapat diangkat dalam konteks ini, yaitu: 1) Bagaimana konsep nilai-nilai kearifan lokal (kepemimpinan) dalam budaya Jawa?; 2) Bagaimana nilai-nilai kearifan lokal (kepemimpinan) Jawa diimplementasikan oleh masyarakat Jawa di Suriname?

\section{Kerangka konseptual}

Nilai kerukunan diwujudkan di tingkat keluarga dan komunitas, di situ hidup harus akrab dan dekat. Orang Jawa memperoleh keamanan psikologis yang cukup besar dari perasaan akrab dan menyatu. Manusia tidaklah sendirian, melainkan merupakan bagian yang tidak terpisah dari suatu kelompok; dalam kelompok itu ia diterima dan ia memainkan peranan; kelompok itu mungkin saja keluarganya, umat (komunitas agama) atau aliran kebatinan serta kelompok teritorial seperti rukun tetangga atau rukun kampung. Agar diterima di dalam kelompoknya orang harus menyesuaikan diri dengan harapan-harapan, bekerjasama, ambil bagian dan sopan. Mengetahui aturan-aturan, bersikap santun, menghormati mereka yang lebih tinggi dan bersikap baik terhadap mereka yang dalam hirarki lebih rendah dan seterusnya amatlah penting untuk menjaga kedudukan seseorang dan untuk memperoleh pengakuan sosial. Ditariknya pengakuan sosial itu merupakan sanksi efektif untuk menghukum orang-orang yang menyimpang, seperti terlihat dalam praktek jothakan di kalangan anak-anak ( Mulder, 1984: 64)

\section{Nilai-Nilai Kearifan Lokal Jawa}

Dalam kehidupan setiap bangsa di dunia dan dalam lingkup kebudayaannya masing-masing, tiap-tiap bangsa itu memiliki kebiasaan hidup (adat-istiadat) yang merupakan aturan tata hidupnya. Kebiasaan suku bangsa yang satu berbeda dengan suku bangsa yang lainnya. Kebiasaan yang telah berpuluhpuluh tahun dianut oleh suatu kelompok masyarakat atau suku bangsa itu dikenal sebagai tradisi dari kelompok masyarakat atau suku bangsa bersangkutan. Suku bangsa Jawa sendiri dikenal sebagai salah satu suku bangsa di Indonesia yang memiliki tradisi kokoh yang masih bertahan sampai saat ini. Sepanjang sejarahnya, segala jenis pengaruh kebudayaan yang berasal dari luar selalu berkembang dan akhirnya membentuk wujud baru tanpa meninggalkan ciri khas kejawaannya yang tradisional. (Budiono Herusatoto, 2011: 1)

Di dalam kebudayaan Jawa dikandung pemikiran tentang hidup dan kehidupan masyarakat Jawa dari masa ke masa dan dimanfaatkan sebaik-baiknya untuk kepentingan peningkatan taraf hidup mereka. Kebudayaan itu sendiri meliputi 3 aspek, yaitu sistem material, sistem perilaku, dan sistem ide - gagasan. 
Pembahasan nilai-nilai kearifan lokal Jawa menyangkut aspek sistem ide gagasan atau pemikiran dibalik perilaku dan benda-benda material yang dihasilkan oleh masyarakat Jawa.

Nilai-nilai kearifan lokal budaya Jawa itu menyangkut berbagai aspek kehidupan, seperti nilai kepemimpinan, toleransi, nasionalisme, keadilan, kebenaran, kejujuran, kesempurnaan, dan sebagainya. Berfilsafat dalam arti luas, di dalam kebudayaan Jawa berarti ngudi kasampurnan. Manusia mencurahkan eksistensinya, baik jasmani maupun rohani, untuk mencapai tujuan itu. Usaha tersebut merupakan suatu kesatuan, suatu kebulatan. Di dalam metafisika, ungkapan tentang ada (alam semesta, Tuhan, dan manusia), dipandang sebagai hasil pemikiran, pengalaman, dan penghayatan manusia, dengan ciri-ciri Tuhan adalah ada semesta, alam semesta merupakan pengejawantahan Tuhan, alam semesta dan manusia merupakan satu kesatuan; pengetahuan yang dicari adalah mengenai dari mana dan ke mana semua wujud ini - sangkan paran (Abdullah Ciptoprawiro, 1986: 21-22). Tentang pengetahuan sangkan paran dan manunggaling kawula gusti telah tergambar di dalam lakon Dewaruci atau Bimasuci.

Di dalam kerangka pemikiran mitis Jawa, manusia menjalin hubungan dengan daya-daya alam dan alam tersebut belum dikacaukan oleh teknologi, lalu lintas, dan turisme, dan bersifat serba rahasia. Pemikiran mitis (van Peursen, 1989: 34-54) ini, hingga sekarang masih dikembangkan dan menjadi pedoman bagi sebagian masyarakat Jawa didalam kehidupan mereka.

Alam semesta, baik manusia, hewan, tumbuhan, gunung, laut, makhluk supranatural, dan sebagainya, merupakan satu kesatuan yang serasi, tidak terlepas satu dengan yang lainnya dan selalu berhubungan. Di dalam hidup dan kehidupannya, manusia selalu menjalin hubungan dengan alam yang melingkupinya. Peristiwa yang terjadi di dunia manusia dipandang sebagai akibat dari ulah yang ditimbulkan oleh lingkungan yang melingkupi manusia itu, atau sebaliknya. Di dalam menjalani atau menapaki hidup dan kehidupannya, manusia memanfaatkan ruang dan waktu. Manusia pun kemudian mengamati pengalaman dan pengetahuan yang diperoleh selama meniti ruang dan waktu tersebut dalam hubungannya dengan lingkungan yang melingkupinya. Hasil dari pengamatan manusia terhadap pengetahuan ruang dan waktu menghasilkan suatu tatanan mengenai ruang dan waktu itu sendiri, seperti diwujudkan di dalam primbon, pawukon, ramalan, dan lain-lain. Jadi pemikiran Jawa memandang alam sebagai satu kesatuan yang utuh. Manusia sebagai mikrokosmos (subjek) pada realitas lehidupannya tidak selalu dalam keselarasan dengan lingkungan yang melingkupinya, yaitu makrokosmos (objek), namun mengalami juga ketidakselarasan. Untuk mengembalikan alam dalam keadaan selaras, biasanya manusia mengadakan upacara atau ritual. Misalnya pandangan terhadap manusia sukerta; manusia oleh karena suatu peristiwa, ia terkena "noda gaib" dan akan menjadi mangsa batara Kala. Peristiwa ini dapat mengakibatkan ketidakseimbangan di dalam kosmos. Peristiwa yang menimpa manusia itu menurut kepercayaan antara lain ontang-anting, kedhana-kedhini, gondhang kasih, dhampit, pendhawa, pendhawi, kembang sepasang, menjatuhkan dandang, mematahkan batu gilasan, menaruh beras di dalam lesung, biasa membakar 
rambut dan tulang, dan membuat pagar sebelum rumahnya jadi (Darmoko, 2002: 32). Sebagai usaha untuk mencegah terjadinya kegoncangan di dalam alam, maka masyarakat Jawa mengadakan upacara ruwatan. Ruwatan ditujukan agar manusia terlindungi dari ancaman mara bahaya. Koentjaraningrat memasukkan upacara ngruwat sebagai ilmu gaib protektif, yaitu upacara yang dilakukan dengan maksud untuk menghalau penyakit dan wabah, membasmi tanaman dan sebagainya, yang sering menggunakan mantra-mantra untuk menjauhkan penyakit dan bencana (1984: 28). Di dalam upacara ruwatan biasanya digelar lakon murwakala dan tokoh sentralnya adalah Kala. Secara fisik dalam dunia wayang, batara Kala digambarkan sebagai makhluk raksasa yang tinggi besar menyeramkan dan menakutkan. Ia sebagai anak batara Guru dari proses kelahiran yang tidak wajar (kelahiran Kala bermula dari sebuah peristiwa yang dialami oleh batara Guru ketika bercengkerama di angkasa dengan menaiki lembu/ sapi Andini bersama dewi Uma, isterinya. Batara Guru timbul hasrat seksnya, namun Uma menolak karena bukan pada tempatnya, sehingga air mani batara Guru jatuh ke laut, lama kelamaan menggumpal dan lahirlah Kala). Batara Kala memangsa mencari mangsa manusia di dunia, ini menjadi kekhawatiran para dewa (batara Narada dan batara Wisnu). Oleh sebab itu batara Wisnu kemudian turun ke dunia sebagai dalang bernama dalang Kandhabuwana atau dalang Sejati untuk menghentikan niat batara Kala. Batara Wisnu bersama dengan dewa lainnya berhasil menghentikan hasrat batara Kala dengan membaca rahasia kelemahan batara Kala, yaitu membaca mantra carakan balik, setra bedhati, sepigeni, sepiangin, sepibanyu, sepibumi, kalacakra, dan pesinggahan. Batara Kala dalam konteks ini dapat diartikan sebagai waktu. Waktu selalu menjadi acuan bagi manusia dalam mengarungi bahtera hidup dan kehidupannya. Manusia yang tidak dapat mengendalikan dan menguasai sang waktu akan terlindas, tergilas, dan dimangsa oleh sang waktu. Oleh karena itu waktu bagi umat manusia diupayakan dapat dikelola, dikendalikan, dan dikuasai agar dalam menapaki hidup ini manusia selalu dalam keadaan survival, kokoh, dan sentosa.

Nilai-nilai kearifan lokal (kepemimpinan) Jawa tergambar didalam berbagai hasil karya budaya, seperti babad, wulang, wayang, suluk, dan sebagainnya. Sebagian besar karya budaya tersebut menguraikan tentang hubungan antara raja dengan rakyat dan raja dengan Tuhan. Sebagai contoh: adegan pertama (jejeran) pada petunjuk wayang kulit purwa. Dikisahkan bahwa raja (pemimpin) yang utama (terpuji dan berderajat tinggi) jika memiliki dan mengimplementasikan sifat berbudi (memberi hadiah/ ganjaran dan memberi penghargaan bagi yang berjasa bagi bangsa dan negara) bawaleksana (segala sesuatu yang diucapkan/ diperintahkan tidak dapat ditarik/ diubah harus dapat dilaksanakan sebaik-baiknya). Ungkapan yang mengandung filosofi moralitas kepemimpinan juga terdapat pada sabda pandhita ratu tan kena wola-wali, secara harfiah artinya adalah ucapan pendeta dan raja tidak boleh diulang-ulang. Maknanya adalah bahwa seorang pemimpin haruslah konsekwen untuk melaksanakan atau mewujudkan apa yang telah diucapkannya, apapun akibatnya. Dalam khasanah bahasa Indonesia sebenarnya kita pun memiliki ungkapan semacam itu, yaitu satunya kata dan perbuatan (Sujamto, 1992: 21; G. Moedjanto, 1987: 35; Sunoto, 1987: 42). 
Raja merupakan wakil Tuhan didunia (ratu pinangka wakiling hyang agung). Sifat -sifat raja merupakan sifat-sifat Tuhan, kebijaksanaan raja sebagai manifestasi dari kebijaksanaan Tuhan. Seperti contoh suluk perdalangan "pathet Lasem Slendro nem" berikut ini: "O...O... dene utaming nata, berbudi bawa leksana, O..., lire berbudi mangkana, O..., lila legawa ing driya, O..., agung dennya paring dana, anggeganjar saben dina, lire kang bawa leksana, O..., anetepi pangandika, O... O... (adapun keutamaan seorang raja, berbudi bawa leksana, maksudnya berbudi demikian: rela dan tulus ikhlas hatinya untuk menjalankan tugas dan kewajiban, banyak memberikan bantuan dana, memberikan ganjaran setiap hari, maksudnya bawaleksana, yakni: konsisten dalam berbicara).

Kutipan tersebut menggambarkan seorang raja (pemimpin) yang terpuji dan memiliki derajat tinggi yaitu yang memiliki dan mengimplementasikan sifat rela dan tulus ikhlas hatinya, banyak memberikan dana, memberikan ganjaran setiap hari, dan konsisten serta konsekwen dalam berbicara. Raja sebagai wakil Tuhan di dunia, oleh sebab itu tutur kata, sikap, dan tindakannya menggambarkan sifat-sifat Tuhan. Keteladanan sebagai raja (pemimpin) tergambar dalam menjalankan penegakan hukum sesuai aturan yang disepakati atau yang berlaku di sebuah negara, yaitu berprinsip pada dana wesi asat. Raja atau pemimpin sebagai pengayom rakyat jika menjatuhkan hukuman harus setimpal dengan perbuatan yang dilakukan, tidak berat sebelah, harus adil dan tanpa memandang siapa yang melakukan kejahatan terhadap tatanan hukum itu, meskipun saudara, anak raja, ataupun pejabat istana sama saja derajatnya dimata hukum.

Sifat rela (rila/ lila) dan tulus ikhlas (legawa) sebagai manifestasi dari tindakan dari darma (tugas suci) sebagai raja. Implementasi dari sifat lila legawa ini disertai sikap menerima (nrima) segala sesuatu paristiwa yang terjadi sebagai sesuatu yang telah menjadi kehendak Tuhan, dalam hal ini bukan berarti sebagai manusia Jawa kemudian bersikap apatis, pasrah sebelum berusaha, namun juga harus berjuang untuk menggapai kehidupan yang lebih baik. Setelah perjuangan telah membuahkan hasil, maka manusia wajib menerima secara ikhlas segala sesuatu yang telah diberikan dan didapatkan itu, apa pun bentuknya dan seberapapun banyaknya rezeki yang diperolehnya, karena segala yang diterimanya itu merupakan kepastian yang diberikan kepada manusia dan dipandang sebagai bagian dari keadilan Illahi; dan jika manusia mendapat panduming Gusti kurang memadai maka diharuskan memiliki dan mengekspresikan sifat dan sikap sabar.

Manusia yang telah berpedoman pada nilai kearifan lila legawa, nrima, dan sabar niscaya tidak akan memiliki dan mengekspresikan sifat dan sikap protes, menggerutu, ngundamana (mempersalahkan) terhadap Tuhan. Namun untuk menggapai kondisi ini manusia biasanya melatih atau mengolah rohani dengan cara tertentu, misalnya puasa senin-kamis, puasa yang dilakukan pada hari Senin dan Kamis. Ini sebagai wujud olah rohani untuk mengendalikan hawa nafsu, mutih, seseorang hanya makan nasi saja; sebagai wujud dari cara seseorang berlatih mengendalikan atau mengelola nafsu makan yang berlebihan, ngebleng, seseorang tidak makan dan tidak minum selama kurun waktu tertentu. Ada yang melakukannya dalam waktu 3 hari, 7 hari, dan bahkan ada yang lebih. 
Nilai kearifan lokal Jawa yang berprinsip pada nilai kepemimpinan tergambar pula di dalam ajaran Ki Hajar Dewantara (1889-1959), seorang pendiri Taman Siswa di Yogyakarta, yaitu: ing ngarsa sung tuladha, ing madya mangun karsa, dan tutwuri handayani. Seorang pemimpin jika berada di depan seyogyanya memberi contoh/ keteladanan yang baik, utama, terpuji, sehingga rakyat tidak terombang-ambingkan oleh ketidakpastian oleh keadaan; jika di tengah mampu menggerakan motivasi, inisiatif, kreatif dan inovatif, sehingga rakyat memiliki kehendak untuk menggapai sesuatu; dan jika di belakang maka pemimpin memberikan kekuatan, semangat, dan kesentosaan batin rakyat.

$\mathrm{Ki}$ Hajar Dewantara sebagai tokoh pejuang pendidikan cinta akan kemerdekaan dan budaya bangsanya sendiri. Gelar keningratannya, Raden Mas, ditanggalkan agar lebih dekat dengan rakyat disemua lapisan. Pendidikan dan kebudayaan sebagai modal dan taktik untuk melepaskan diri dari belenggu penjajahan. Dengan demikian pendidikan memadai dan berwawasan luas, keinginan merdeka semakin dapat diwujudkan. Pemikiran Ki Hajar Dewantara mengenai pendidikan dan kebudayaan, dapat dirumuskan kedalam lima konsep pemikiran yang bermuara pada nasionalisme. Pertama "konsep keselarasan/ keseimbangan"; ia melakukan kritik yang tajam pelaksanaan pendidikan ala barat yang di pandang lebih menonjolkan intelektualitas rasio sehingga menjadikan menusia sebagai mesin, robot, benda hidup semata, karena hal ini merupakan anti keselarasan/ keseimbangan; kedua "konsep kebangsaan"; pendidikan yang diterapkan di pereguruan Taman Siswa berdasarkan nilai-nilai kebangsaan yang hakiki. Kenyataan masyarakat Indonesia terdiri dari berbagai agama, suku, budaya, namun hendaknya hal itu dipandang sebagai dasar pengembangan sistem pendidikan bangsa. Tujuan pendidikan yaitu memajukan bangsa secara menyeluruh yang didalamnya terdapat perbedaan; ketiga "konsep budi pekerti"; pendidikan budi pekerti menjadi ciri khas pengembangan sistem pendidikan, disamping memiliki intelektual tinggi juga berbudi pekerti luhur, karena budi pekerti sebagai modal utama pengembangan diri dalam masyarakat; kempat "konsep kepribadian budaya bangsa"; kebudayaan bangsa sendiri merupakan roh pendidikan. Pengembangan pendidikan bertumpu pada kebudayaan sendiri, meskipun tidak menolak kebudayaan asing yang datang. Kebudayaan asing yang masuk diolah dan diselaraskan dengan kebudayaan bangsa; kelima "konsep kekeluargaan"; pendidikan dilaksanakan secara kekeluargaan ditandai suasana yang akrab dan bersahabat antar pamong, siswa, dan pamong dengan siswa. Pendidikan sistem among dikembangkan agar tercipta keseimbangan organisasi.

Nilai kearifan lokal budaya Jawa yang terkait dengan nasionalisme tersebut di atas sebelumnya telah digambarkan oleh KGPAA Mangkunagara I (Raden Mas Said atau Pangeran Samber Nyawa), yaitu rumangsa melu handarbeni, rumangsa melu hangrukebi, mulat sarira hangrasa wani. Sebagai calon pemimpin maupun sebagai rakyat hendaknya memiliki sifat merasa memiliki; merasa turut berjuang membela dan mempertahankan; dan mampu introspeksi atau mawas diri, artinya dapat mengukur eksistensi diri sendiri. Ungkapan tersebut mengisyaratkan agar seluruh lapisan masyarakat Jawa dimanapun dan kapanpun hendaknya memiliki prinsip dasar hidup berbangsa dan bernegara yaitu nasionalisme, tanpa memandang suku, agama, ras dan golongan. 
Seluruh rakyat bersatu padu untuk membangun tatanan hidup berbangsa dan bernegara agar tercipta suasana aman, damai, dan sejahtera atau dalam istilah dalam dunia pedalangan dan perwayangan gemah, ripah, loh, jinawi, tata, tentrem, karta, dan raharja (terciptanya tatanan sosial yang aman, damai dan sejahtera).

Nilai kearifan lokal budaya Jawa yang berorientasi pada keutamaan seorang pemimpin juga tergambar di dalam lakon wayang berjudul Wahyu Makutarama, yang mengisahkan pemberian anugerah dewata (wahyu) berupa ajaran atau tuntunan berisi pengetahuan tentang keutamaan (derajat tinggi) seorang pemimpin. Sang Hyang Suman (Wisnu-Kresna) memberikan wejangan keutamaan bagi seorang pemimpin kepada Arjuna sebagai calon pemimpin atau manusia yang akan menurunkan benih pemimpin/ raja. Ajaran ini berisi delapan keteladanan sifat alam (asthabrata), yaitu: 1) watak surya - matahari, sebagai seorang pemimpin hendaknya memberi daya kekuatan kepada semua yang ada di dunia. Semua yang ada di dunia mendapatkan daya kekuatan dari sinar matahari. Lautan menguap kemudian mendatangkan hujan, tanaman dan tumbuh-tumbuhan dapat hidup, juga karena pengaruh dari sinar matahari. Untuk keutamaan raja ibaratnya memberi payung kepada orang yang terkena hujan dan panas, memberi tongkat kepada orang yang berjalan di tempat licin, memberi makanan kepada orang yang kelaparan, memberi air kepada orang yang kekeringan, memberi pakaian kepada orang yang telanjang, menyembuhkan/ mengobati orang yang yang sakit, dan membangun kebahagiaan kepada orang yang prihatin. Sebagai pemimpin negara harus senantiasa memberikan motivasi, dorongan, dan semangat yang positif dan konstruktif kepada rakyatnya; 2) watak candra - bulan, sebagai seorang pemimpin senantiasa mengemong masyarakat dan berusaha untuk meningkatkan ilmu pengetahuan. Sebagai pemimpin negara harus selalu memberikan kesejukan bagi rakyatnya dalam keadaan apapun; 3) watak kartika bintang, sebagai seorang pemimpin hendaknya kokoh fikiran dan tekadnya. Semua tindak-tanduk yang dilakukan berdasarkan pada kokohnya fikiran dan tekad serta kesabaran untuk menggapai cita-cita. Sebagai seorang pemimpin negara hendaknya senantiasa memberikan keteladanan kepada rakyatnya tentang kokoh dan kuatnya akal dan fikiran, kesentosaan serta tekad untuk membangun bangsa dan negara; 4) watak akasa - angkasa, sebagai seorang pemimpin senantiasaa mengelola dan mengendalikan keadaan apapun. Sifat angkasa dapat menampung seluruh isi alam. Bagi pemimpin ibarat fikiran meneropong dan menerawang jauh dan luas, tidak sembarang orang dapat mengukur apa yang difikirkannya itu. Sebagai seorang pemimpin negara harus dapat mengelola dan mengendalikan masalah yang menimpa bangsanya; 5) watak kisma - bumi, sebagai seorang pemimpin hendaknya murah hati kepada siapa saja yang memohon untuk diberi kemurahan itu, karena sifat bumi jika ditanami apa saja akan membuahkan hasil yang berlipat ganda, sehingga akan memberikan kebahagiaan yang menanamnya. Namun siapa saja yang malas untuk menggarap tanah dan bercocoktanam tidak akan menikmati hasil bumi yang dapat memberi kejseahteraan. Sebagai seorang pemimpin negara harus memiliki watak berbudi, berarti senantiasa bermurah hati kepada rakyatnya; 6) watak dahana - api, sebagai seorang pemimpin hendaknya menjadi pembasmi keangkaramurkaan yang 
senantiasa menyebabkan kerusakan dunia dan melanggar tatanan hukum/ aturan dunia, ibarat membabadi tanaman/ tumbuh-tumbuhan yang terlalu lebat. Sebagai seorang pemimpin negara harus memiliki kekuatan mental dalam menegakkan hukum negara dan memberikan hukuman yang sepadan dengan perbuatannya kepada siapapun tanpa memandang suku, agama, ras, dan golongan manapun; 7) watak tirta - air, sebagai seorang pemimpin hendaknya senantiasa mengutamakan reasa toleransi dan kebersamaan, karena air memiliki sifat rata. Sebagai seorang pemimpin harus selalu mengedepankan watak duduk sama rendah berdiri sama tinggi kepada rakyatnya; 8) watak samirana - angin, sebagai seorang pemimpin hendaknya bersifat adil secara proporsional. Seluruh isi alam senantiasa dilingkupi oleh angin/ udara. Bagi seorang raja di dalam mengemong masyarakat, baik tua maupun muda, strata sosial tinggi atau rendah, senantiasa berusaha membangun rasa kebahagiaan. Sebagai seorang pemimpin negara harus senantiasa bertindak adil kepada rakyatnya. Pemberian dan pembagian atas hasil bumi dan kekayaan lain hendaknya dilakukan secara adil dan proporsional. (Siswoharsojo, 1957: 136-137)

Sistem pengetahuan yang ada di dalam ajaran asthabrata tersebut menunjukkan bahwa karakter manusia Jawa sebagai calon pemimpin identik dengan karakter alam. Sistem ideologi kepemimpinan, yaitu sesuatu yang hendak digapai atau dicita-citakan, dalam hal ini seorang pemimpin yang betul-betul ideal menurut pemikiran Jawa dengan cara membentuk, meneladani, dan mengidentikan dirinya dengan sifat-sifat alam.

Nilai-nilai kearifan lokal budaya Jawa yang pantas untuk dikembangkan juga yaitu sikap toleransi terhadap sesama hidup, amemangun karyenak tyasing sasama, yang berarti berusaha menciptakan suasana hati yang harmonis antara manusia yang satu dengan yang lain di dalam hidup bermasyarakat, berbangsa dan bernegara. Sebagai acuan prinsip hidup ini, perhatikan cuplikan tembang pupuh Sinom dari Serat Wedhatama karya KGPAA Mangkunagara IV berikut ini: "Nulada laku utama, tumraping wong tanah Jawi, wong agung ing Ngeksiganda, Panembahan Senapati, kepati amarsudi, sudane hawa lan nepsu, pinesu tapa brata, tanapi ing siyang ratri, amemangun karyenak tyasing sasama" (Teladanilah laku/ jalan hidup yang utama, bagi masyarakat yang ada di Jawa, yakni raja Mataram, Panembahan Senapati, berusaha melatih dengan sungguhsungguh, berkurangnya hawa nafsu, berupaya pula untuk melakukan tapabrata, baik di waktu siang maupun malam, berusaha menciptakan suasana hati yang harmoni dengan sesama hidup).

Kutipan di atas memberikan gambaran bahwa orang Jawa terutama bagi seorang pemimpin hendaknya memiliki landasan hidup untuk melatih rohani dengan cara terus menerus mengurangi hawa nafsu melalui tapabrata, baik di waktu siang maupun malam seperti dilakukan oleh raja Mataram, Panembahan Senapati, sewaktu masih muda bernama Sutawijaya. Ia berhasil menaklukkan dan membunuh Arya Penangsang, adipati dari Jipang, sehingga kemudian raja Pajang, Sultan Hadiwijaya memberikan hadiah berupa tanah, untuk Sutawijaya. Oleh karena Sutawijaya masih muda maka hadiah itu diterima oleh Ki Pemanahan berupa tanah Mataram. Sedangkan Ki Penjawi diberi hadiah oleh Sultan Adiwijaya yaitu tanah Pati. 
Nilai kearifan lokal budaya Jawa yang berorientasi pada semangat untuk bekerja dan bekerja bersama-sama, yaitu sepi ing pamrih rame ing gawe, berarti tidak mendahulukan sikap pamrih/ hasrat untuk memiliki dan menguasai sesuatu (harta, tahta, wanita) namun mengedepankan/ mendahulukan sikap beramairamai, tekun, rajin untuk melakukan pekerjaan. Seseorang mendapatkan hadiah. Rezeki, atau imbalan lainnya berdasarkan ketekunan, keuletan, dan kwalitas dalam bekerja, bukan sebaliknya mengharapkan dahulu hadiah/ imbalan sementara belum memulai untuk bekerja dan gotong-royong, ditunjukkan oleh sebuah tembang/ lagu Gugur Gunung, yang sudah tersebar luas khususnya di dalam dunia karawitan, pedalangan, dan perwayangan, seperti kutipan berikut: "Ayo kanca ayo kanca ngayahi karyaning praja, kene kene kene kene gugur gunung tandang gawe, sayuk sayuk rukun bebarengan ro kancane, lila lan legawa kanggo mulyaning Negara; siji loro telu papat maju papat papat, diulang ulungake mesthi enggal rampunge, holobis kontul baris holobis kontul baris, holobis kontul baris holobis kontul baris" (Marilah kawan marilah kawan melaksanakan pekerjaan negara, sini sini sini sini bersama-sama melaksanakan pekerjaan itu, kompak dan rukun bersama-sama kawan, tulus ikhlas demi kemuliaan negara; satu dua tiga empat maju empat empat, diberikan secara gayung bersambut pasti segera selesai, serentak bagai (burung) Kuntul berbaris $(2 \mathrm{x})$, serentak bagai (burung) Kuntul berbaris $(2 \mathrm{x})$ ).

Kutipan tersebut menggambarkan betapa kompaknya suatu kelompok masyarakat (Jawa) untuk menjalankan tugas dan kewajiban sebagai warga negara tanpa memandang suku, agama, ras, golongan hingga mereka dapat menyelesaikan suatu pekerjaan.

Untuk membangun kebersamaan antar warga, perlu dikembangkan juga sikap mad-sinamadan (saling memberi sesuatu, saling mengemong) dan dayadinayan (saling memberi kekuatan). Prinsip hidup demikian ini jika dilaksanakan dengan baik, benar, dan tepat maka akan tercipta suasana rukun dan saling menghormati diantara warga masyarakat. Suasana rukun dan saling menghormati diantara warga masyarakat ini tentu saja akan menuju dan membentuk tatanan kehidupan manusia yang aman, damai, dan sejahtera.

\section{HASIL PENELITIAN DAN PEMBAHASAN}

\section{Implementasi nilai-nilai kearifan lokal Jawa di Suriname}

Tulisan ini bukan merupakan penelitian yang didasarkan atas pengamatan langsung terhadap gejala sosial budaya masyarakat Jawa di Suriname, namun tidak lain sebagai interpretasi tahap awal terhadap nilai-nilai kearifan lokal Jawa yang diterapkan oleh masyarakat Jawa di Suriname beberapa tahun belakangan ini. Informasi data diperoleh dari beberapa pegawai KBRI Suriname di Paramaribo, baik yang masih aktif maupun yang telah selesai bertugas di sana dan jejaring sosial (google).

Berdasarkan sensus tahun 2004, jumlah dan komposisi penduduk Suriname berdasarkan etnis, yaitu Hindustan 135.117 orang $(27,4 \%)$, Creole $87.202(17,7 \%)$, Bushnegro dan Maroon 72.553 orang $(14,7 \%)$, Jawa 71.879 orang (14,6\%), Campuran 61.524 orang (12,5\%), Amerindian 18.037 orang (3.7\%), Cina 8.775 orang (1,8\%), Kulit Putih - Belanda dan lain-lain 2.264 orang 
(0,5\%), Lain-lain etnis 2.264 orang $(0,5 \%)$, dan tidak dikenal 32.579 orang (6,6\%). Jumlah penduduk seluruhnya 492.829 orang. Menurut beberapa sumber antara lain Suriname Embassy di Jakarta, saat ini jumlah penduduk Suriname lebih dari 500.000 orang. Sedangkan Amerindian adalah penduduk asli Suriname, pada tahun 1964 merupakan 2\% jumlah penduduk dan pada tahun 2004 sudah mendekati $4 \%$.

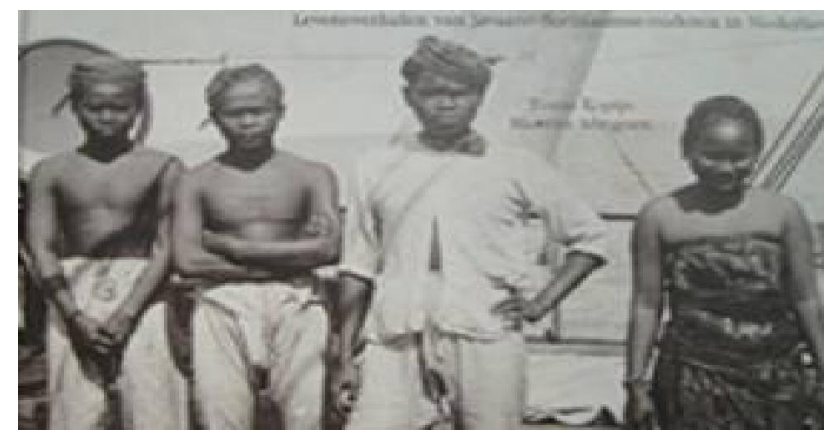

Buruh kontrak orang-orang Jawa di Suriname sedang berfoto http://sejarahbangsaindonesia.fi les.wordpress.com/2011/05/imig ran-jawa-surinamemain.jpg? $w=570$

Etnis Hindustan sebagian besar dibawa oleh penjajah Inggris sebelum pecah adanya negara India dan Pakistan. Creole keturunan budak-budak dari Afrika yang nenek moyangnya dibawa oleh penjajah Inggris pada abad ke-17 dan ke-18 terutama dari Ghana. Maroon merupakan keturunan budak-budak dari Afrika yang melarikan diri dan tinggal di pedalaman hutan - hutan Suriname. Etnis Jawa di Suriname berasal dari pulau Jawa, kebanyakan Jawa Tengah, sebagian kecil Jawa Timur dan Jawa Barat, diangkut ke Suriname oleh penjajah Belanda mulai tahun 1890, dipekerjakan terutama di berbagai perkebunan kopi, cokelat, dan tebu. Sampai dengan tahun 1949 orang-orang Jawa yang tinggal di Suriname berjumlah 37.596 orang.

Suriname sebagai negara kecil berpenduduk multi etnis, sekilas kehidupan sosial - budaya dalam masyarakat tampak saling menyadari adanya keberagaman etnis sebagai pendatang di Suriname, dan mereka mulai menyadari pula perlunya semangat nasionalisme Suriname, tetapi masing-masing etnis juga mempunyai ikatan (keterikatan) yang didasari oleh asal usul negara mereka. Misalnya, etnis Cina mendirikan sekolah berbahasa Cina, etnis Hindustan mendirikan sekolah India dan seni tari India, yang orientasi ke Pakistan bergerak dalam kegiatan di lingkungan umat Islam. Sedangkan Etnis Jawa kurang kuat posisinya sehingga KBRI banyak membantu mereka untuk menyelenggarakan kursus bahasa Jawa dan bahasa Indonesia, kursus tari Jawa, Bali dan lain-lain. Sebulan (beberapa waktu) yang lalu Salam Somohardjo, Ketua Partai politik Pertjaja Luhur datang di Indonesia untuk kesekian kalinya (sangat sering ke Indonesia), antara lain mencari guru dalang muda yang multi profesi, di samping mengajar pedalangan wayang kulit dan karawitan juga dapat bekerja lain, seperti menjadi penyiar radio, tv Jawa, tukang jahit, bertani, ternak dan lain-lain. Guru tersebut diberi penghasilan per bulan US\$ 600, tiket ke Suriname pulang pergi, paspor, visa, akomodasi, makan, transpor lokal di Suriname dan lain-lain, semua ditanggung pihak Suriname, dan diharapkan tinggal minimal 6 bulan di sana, namun dapat 
diperpanjang. Demikian pula etnis lain mengembangkan seni - budaya etnisnya sendiri-sendiri. Tetapi cukup sering ada pergelaran seni gabungan etnis yang dimotori oleh orang-orang Jawa Suriname bertempat di gedung Sana Budaya Paramaribo.

Di bidang ekonomi yang menonjol adalah etnis Hindustan dan Cina mereka sudah mulai melakukan bisnis dalam skala menengah seperti pabrik air minum mineral, superstores, restoran bintang lima. Sedangkan keturunan Jawa yang cukup menonjol mengadakan usaha makanan kering, krupuk udang, kue, makanan kelas warung, baik warung besar maupun kecil.

Di bidang politik didominasi oleh etnis Hindustan dan Creole dan presiden Desi Bouterse sendiri berdarah campuran. Menteri keturuan Jawa saat ini adalah Menteri Pendidikan dan Menteri Dalam Negeri. Dalam kepartaian (politik) didominasi etnis Hindustan dan Creole, hanya saja dari tahun 2005 - 2010 Ketua Parlemen dipegang keturunan Jawa, yaitu Salam Somohardjo dan ia mencalonkan presiden untuk Suriname, tetapi belum berhasil.

Perselisihan atau pertikaian antar suku bangsa pernah terjadi di Suriname. Pada tanggal 25 Februari 1980 terjadi kudeta militer dipimpin oleh Desi Bouterse menembak mati tokoh-tokoh oposisi yang sebagian besar keturunan Hindustan. Sejak itu di Suriname terus terjadi kekacauan. Pada tahun 1986 terjadi perang saudara (civil war) oleh etnis Maroon melawan pemerintahan Bouterse, tetapi etnis lain juga turut melawan dan menjadi korban. Maka kejadian ini memicu eksodus orang-orang Suriname ke Belanda termasuk etnis Jawa. Suku bangsa Jawa pada saat itu banyak yang menjadi korban dari kekacauan yang terjadi dan tidak aktif dalam peperangan. Suku bangsa Jawa lebih cenderung memberikan keteladanan dan dorongan-dorongan agar yang saling berttikai untuk berdamai. Suku bangsa Jawa bersikap tidak agresif, perasaan sebagai "pendatang rombongan akhir" di Suriname masih terasa pada sikap para tokoh Jawa di Suriname, di samping mental Jawa yang andhap asor (rendah hati), juga wong ngalah luhur wekasane (orang mengalah pada akhirnya akan meninggikan derajad), dan ana catur mungkur (ada pembicaraan yang tidak baik mengenai seseorang atau kelompok orang lebih baik tidak turut campur dan menghindar), masih cukup terpatri dalam sanubari mereka. Sifat dan sikap yang dipilih dan ditunjukkan oleh etnis Jawa di Suriname merupakan nilai-nilai dan norma-norma kearifan lokal Jawa yang masih berusaha dipertahankan, dikembangkan, dan diemplementasikannya di Suriname.

Nilai-nilai dan norma-norma kehidupan yang tumbuh di dalam masyarakat berguna untuk mencari keseimbangan dalam tatanan kehidupan. Nilai-nilai dan norma-norma itu dibentuk sesuai dengan kebutuhan masyarakat setempat, yang akhirnya menjadi adat-istiadat. Adat-istiadat diwujudkan dalam bentuk tata upacara (Thomas Wiyasa Bratawijaya, 1988: 9). Seperti halnya masyarakat Jawa di Suriname, yang masih menjalankan tradisi atau adat istiadat yang dibawa dari Pulau Jawa ke Suriname, meskipun telah terjadi perubahan karena faktor semakin jauhnya jarak pewarisan budaya dari generasi pertama Jawa di sana hingga anak dan cucu mereka. Di dalam filosofi moralitas Jawa tergambar dengan jelas bahwa orientasi kehidupan mereka menekankan pada aspek-aspek yang bersifat batin. Dalam pembicaraan mengenai kebatinan diketahui bahwa rasa batin, atau indera 
keenam, diakui sebagai alam kehidupan yang benar-benar penting. Secara praktis pengembangan batin seseorang dinyatakan dalam kecdenderungan umum untuk menyimpan diri sendiri, untuk kerasan dengan diri sendiri, dan berhati-hati untuk tidak diganggu oleh apa saja yang terjadi di luar. Ketika diwawancarai mengenai etika Jawa, seorang guru mistik yang agak pragmatis menyatakannya sebagai apa saja yang baik untuk batin seseorang adalah baik. Kalau orang menyesuaikan diri dengan bentuk-bentuk dan harapan-harapan sosial sambil menghindari pertikaian dan gangguan, orang dapat mencegah dunia luar menyusup ke dalam batinnya. Oleh karena itu orang dapat menikmati rasa nyaman dari ketentraman batin, menyerahkan diri kepada lamunan-lamunan (nglamun), atau menumbuhkan potensi batinnya, menaruh perhatian pada kejadian-kejadian dalam dirinya atau mendengarkan kepada suara dalam kesepian. Disebabkan oleh cita-cita ini kebudayaan Jawa sangat kaya sekali akan petuah bijaksana untuk menjaga agar kehidupan masyarakat teratur, baik dan damai, tidak sebagai tujuan dalam sendirinya, tetapi penguasaan atas dunia luar mendatangkan ketenangan batin seperti keadaan tentram (tentrem) yang setengah sosial dan setengah psikologis dan perasaan pribadi mendalam mengenai kepuasan yang tenang (ayem). Untuk dapat menikmati kepuasan itu orang harus belajar menguasai emosi-emosinya sambil mengikuti aliran masyarakat (ngeli), menanamkan ketahanan (sabar), rendah hati (andhap asor), dan kemampuan untuk menerima kemalangan dengan anggun dengan harapan akan mengalami hari esok yang lebih baik (nrima). Beberapa orang akan menyerah begitu saja (pasrah) pada kehidupan sebagaimana adanya, tetapi kepasrahan ini merupakan sikap yang kurang dikehendaki (Mulder, 1985: 69).

Secara lebih mendalam sikap batin tersebut diperdalam oleh Franz Magnis Suseno bahwa prinsip kerukunan bertujuan untuk mempertahankan masyarakat dalam keadaan yang harmonis. Keadaan semacam itu disebut rukun. Rukun berarti "dalam keadaan selaras", "tenang dan tentram", "tanpa perselisihan dan pertentangan", "bersatu dalam maksud untuk saling membantu". Keadaan rukun terdapat di mana semua pihak berada dalam keadaan damai satu sama lain, suka bekerjasama, saling menerima, dalam suasana tenang dan sepakat. Rukun adalah keadaan ideal yang diharapkan dapat dipertahankan dalam semua hubungan sosial, dalam keluarga, dalam rukun tetangga, di desa, dalam setiap pengelompokan tetap. Suasana seluruh masyarakat seharusnya bernapaskan semangat kerukunan. Kata rukun juga menunjuk cara bertindak. Berlaku rukun berarti menghilangkan tanda-tanda ketegangan dalam masyarakat atau antara pribadi-pribadi, sehingga hubungan-hubungan sosial tetap kelihatan selaras dan baik-baik. Rukun mengandung usaha terus menerus oleh individu untuk bersikap tenang satu sama lain dan untuk menyingkirkan unsur-unsur yang mungkin menimbulkan perselisihan dan keresahan. Tuntutan kerukunan merupakan kaidah penata masyarakat yang menyeluruh. Segala apa yang dapat mengganggu keadaan rukun dan suasana keselarasan dalam masyarakat harus dicegah (1993: 39)

Kaidah kedua yang memainkan peranan besar dalam mengatur pola interaksi dalam masyarakat Jawa ialah prinsip hormat. Prinsip itu mengatakan bahwa setiap orang dalam cara bicara dan membawa diri selalu harus menunjukkan sikap hormat terhadap orang lain sesuai dengan derajad dan 
kedudukannya. Apabila dua orang bertemu, terutama dua orang Jawa, bahasa, pembawaan dan sikap mereka mesti mengungkapkan suatu pengakuan terhadap kedudukan mereka masing-masing dalam tatanan sosial yang tersusun dengan terperinci dan cita rasa. Mengikuti aturan-aturan tata krama yang sesuai, dengan mengambil sikap hormat atau kebapakan yang tepat adalah amat penting. Prinsip hormat berdasarkan pendapat, bahwa semua hubungan dalam masyarakat teratur secara hirarkis, bahwa keteraturan hirarkis itu bernilai pada dirinya sendiri dan oleh karena itu orang wajib untuk mempertahankannya dan untuk membawa diri sesuai dengannya. Pandangan itu sendiri berdasarkan cita-cita tentang suatu masyarakat yang teratur baik, dimana setiap orang mengenal tempat dan tugasnya dan dengan demikian ikut menjaga agar seluruh merupakan satu kesatuan yang selaras. Kesatuan itu hendaknya diakui oleh semua dengan membawa diri sesuai dengan tuntutan-tuntutan tata krama sosial. Mereka yang berkedudukan lebih tinggi harus diberi hormat. Sedangkan sikap yang tepat terhadap mereka yang berkedudukan lebih rendah adalah sikap kebapakan atau keibuan dan rasa tanggung jawab. Kalau setiap orang menerima kedudukannya itu maka tatanan sosial terjamin. Oleh karena itu orang jangan mengembangkan ambisi-ambisi, jangan mau bersaing satu sama lain, melainkan hendaknya setiap orang puas dengan kedudukannya yang diperolehnya dan berusaha untuk menjalankan tugasnya masing-masing dengan sebaik-baiknya: ambisi, persaingan, kelakuan kurang sopan, dan keinginan untuk mencapai keuntungan material pribadi dan kekuasaan merupakan sumber bagi segala perpecahan, ketidakselarsan, dan kontradisksi yang seharusnya dicegah dan ditindas (Suseno, 1993: 60).

Sosok manusia utama dalam konsep religiusitas Jawa berdimensi pada dua wilayah: 1) kepada sesama manusia (horisontal); 2) kepada Tuhan (vertikal). Pergaulan manusia yang bersifat horisontal terwujud dalam simbol bahasa yang berbunyi bisa ajur-ajer (mampu beradaptasi dan menyeleksi). Konsep ini menganjurkan kepada orang Jawa agar selalu dapat menempatkan dirinya secara adaptif dimanapun berada. Bergaul dengan daya empati yang tinggi. Artinya, mampu merasakan dan memahami kesulitan tetangga. Bahkan pada tingkat yang lebih tinggi, orang Jawa seharusnya bisa dituladha, bisa menjadi panutan. Sehingga dimanapun dirinya bertempat tinggal akan selalu dihormati dan mudah diterima oleh orang lain. Sementara itu dimensi religiusitas orang Jawa yang bersifat vertikal diukur dari pemahaman dan tindakan kongkretnya sebagai kawula (hamba) Tuhan. Menyadari hal itu orang Jawa selalu berusaha menempatkan dirinya secara tepat. Simbol simplikasi kebahasaan semacam ngawula (taat kepada Tuhan) dan mung titah sawantah (hanya hamba sahaya), tepa slira (memahami orang lain) menjadi karakter asli sikap religius orang Jawa. Inilah dasar keimanan yang pada gilirannya melahirkan sejumlah pengakuan keyakinan luar biasa yang sarat spiritualitas: nrima ing pandum, wong mung saderma, sumarah, kabeh wus pinesthi (Mulyana, 2006: 4).

Budaya Jawa, baik yang berkaitan dengan bahasa dan sastra, kesenian, religi dan adat-istiadat, organisasi sosial- budaya- politik, mata pencaharian hidup, teknologi dan peralatan, sistem pengetahuan, yang dibawa dari tanah air Indonesia masih tumbuh dan berkembang dengan baik dan masih cukup terpelihara di Suriname, tetapi dari generasi ke generasi makin rendah kadarnya. KBRI minta 
bantuan ke Indonesia sangat seret responnya dan minim, missal member beasiswa ke Yogya -Solo hanya dua orang itu pun sebagian biaya ditanggung siswa. Idealnya kalau ingin memelihara seni-budaya Jawa di Suriname sebagai permukiman orang Jawa terbesar di dunia di luar Indonesia, seharusnya ada perlakuan khusus kepada Suriname.

Nilai-nilai kearifan lokal Jawa, seperti sikap hormat-menghormati, saling menghargai, tepa slira, mawas diri, toleransi, mad sinamadan dan daya dinayan, serta nilai kebersamaan dan kesamaan dalam berkehidupan masih diterapkan masyarakat Jawa di Suriname. Implementasi nilai-nilai kearifan lokal Jawa tersebut terutama kalau ada kesripahan selalu luber yang melayat, demikian pula acara bersih desa, pesta-pesta lapangan orang Jawa sangat meriah dan ribuan yang hadir, "bada kupat" dalam rangka hari raya lebaran atau Idul Fitri. Nilai-nilai humanis-religius tersebut di atas diimplementasikan juga oleh masyarakat Jawa terhadap suku bangsa yang lain di Suriname, namun tidak seintensif terhadap masyarakat Jawa. Di samping itu kegiatan solidaritas Jawa di Suriname ditunjukkan dengan pergelaran-pergelaran seni dan adat-istiadat lainnya.

Penerapan sikap dan nilai-nilai kearifan lokal Jawa tersebut lumayan efektif untuk menyelesaikan suatu konflik, perselisihan, atau pertikaian masyarakat Suriname yang demikian beragam. Orang Jawa di Suriname dikenal sebagai etnis yang lembut, sopan, pekarangan rumahnya bersih dan rapi. Aspek keteladanan di sini menjadi faktor utama dalam hidup bermasyarakat, berbangsa, dan bernegara (ing ngarsa sung tuladha) sesuai dengan nilai-nilai luhur nenek moyang bangsa Jawa yang mereka bawa ke Suriname. Di bawah naungan nilai kearifan lokal sebagai pemimpin yang memberikan keteladanan kepada masyarakat luas, orang Jawa juga menunjukkan sikap berinisiatif, berkreativitas, dan memotivasi terhadap anggota masyarakat yang lain untuk mewujudkan citacita atau idam-idaman yang disepakati, disadari, dan dipahami bersama (ing madya mangun karsa). Di samping itu sebagai orang Jawa, apalagi seorang pemimpin, peran dan kedudukannya di tengah-tengah masyarakat memberikan perhatian, daya kekuatan, dan dorongan spiritual agar anggota masyarakat yang lain tumbuh semangat mengembangkan kreativitasnya untuk mengerjakan tugas dan kewajiban bersama yang telah dicita-citaklan atau diidam-idamkan itu (tut wuri handayani). Implementasi tentang nilai-nilai kearifan lokal kepemimpinan Jawa ini tentu saja memiliki efektivitas yang cukup optimal di kalangan masyarakat Jawa sendiri namun belum signifikan di antara suku-suku bangsa lain di Suriname, karena hal ini memerlukan waktu untuk mempelajari, memahami, dan menghayati kebudayaan suku bangsa Jawa yang hidup di tengah-tengah kehidupan suku bangsa yang lain di Suriname.

\section{SIMPULAN}

Setelah dikaji, dapat disimpulkan "Nilai Kearifan Lokal Kepemimpinan Jawa Sebagai Solusi Penyelesaian Konflik: Studi Kasus pada Masyarakat Jawa di Suriname", dapat disimpulkan, sebagai berikut:

1). Berprinsip pada filosofi moralitas, nilai-nilai kearifan lokal budaya Jawa pada dasarnya berorientasi pada ngudi kasampurnan (berusaha ke arah kesempurnaan). Manusia mencurahkan eksistensinya, baik jasmani maupun 
rohani untuk mencapai tujuan itu. Usaha tersebut merupakan suatu kesatuan dan kebulatan. Keberadaan tentang alam semesta, Tuhan, dan manusia merupakan hasil pemikiran, pengalaman, dan penghayatan manusia. Di dalam budaya Jawa, pengetahuan yang dicari adalah mengenai dari mana dan akan ke mana semua wujud (keberadaan) ini. Orientasi kehidupan Jawa pun menekankan pada aspek-aspek yang bersifat batin yang pengembangannya secara umum menyatakan untuk menyimpan diri sendiri, untuk kerasan dengan diri sendiri, dan berhati-hati untuk tidak diganggu oleh apa saja yang terjadi di luar. Orang Jawa dapat menikmati rasa nyaman di dalam batinnya, menyerahkan diri kepada lamunan-lamunan (nglamun). Budaya Jawa sangat kaya petuah bijaksana untuk menjaga agar kehidupan masyarakat teratur, baik dan damai, memperoleh ketentraman baik sosial maupun psikologis (tentrem) dan perasaan pribadi mendalam mengenai kepuasan yang tenang (ayem); belajar menguasai emosi-emosinya sambil mengikuti aliran masyarakat (ngeli), menanamkan ketahanan (sabar), rendah hati (andhap asor), dan kemampuan menerima kemalangan secara anggun dengan harapan akan mengalami hari esok yang lebih baik (nrima); menyerah begitu saja (pasrah) pada kehidupan sebagaimana adanya.

2).Prinsip kerukunan dalam budaya Jawa bertujuan untuk mempertahankan masyarakat dalam keadaan harmonis. Rukun artinya kehidupan masyarakat "dalam keadaan selaras", "tenang dan tentram", "tanpa perselisihan dan pertentangan", "bersatu padu untuk saling membantu". Keadaan rukun diperoleh kalau semua pihak berada dalam keadaan damai satu sama lain, suka bekerjasama, saling menerima, dalam suasana tenang dan sepakat. Masyarakat Jawa Suriname masih tampak mengikuti dan melestarikan nilai-nilai kearifan lokal Jawa dengan menciptakan suasana kerukunan di antara anggotanya dengan membentuk ikatan-ikatan persaudaraan baik yang bersifat politik maupun sosial keagamaan.

3). Prinsip hormat dalam budaya Jawa dimaknai, setiap orang dalam cara bicara dan membawa diri selalu menunjukkan sikap hormat terhadap orang lain sesuai dengan derajad dan kedudukannya. Komunikasi di antara orang Jawa tampak dalam bahasa, pembawaan dan sikap mereka dalam mengungkapkan pengakuan terhadap kedudukan mereka masing-masing dalam tatanan sosial yang tersusun dengan terperinci dan cita rasa. Mengikuti aturan-aturan tata krama yang sesuai, dengan mengambil sikap hormat atau kebapakan yang tepat. Prinsip hormat dalam kehidupan masyarakat Jawa teratur secara hirarkis, bahwa keteraturan hirarkis bernilai pada dirinya sendiri dan wajib untuk mempertahankannya untuk membawa diri sesuai dengannya. Kasus pada masyarakat Jawa di Suriname dalam konflik antar suku menunjukkan sikap netral dan berusaha untuk mendamaikan serta memberikan sikap keteladanan untuk hidup rukun dan saling hormat-menghormati di antara suku-suku bangsa yang berselisih, pasca kudeta militer oleh Desi Bouterse.

4). Sikap hormat-menghormati, saling menghargai, tepa slira, mawas diri, toleransi, mad-sinamadan (menunjukkan saling perhatian) dan daya-dinayan (menunjukkan saling memberikan kekuatan), serta nilai kebersamaan dan kesamaan dalam berkehidupan masih diterapkan masyarakat Jawa di Suriname. 
Implementasi nilai-nilai kearifan lokal Jawa tersebut terutama jika ada kesripahan selalu membeludag yang melayat, demikian pula acara bersih desa, pesta-pesta lapangan orang Jawa sangat meriah dan ribuan yang hadir, "bada kupat" dalam rangka hari raya lebaran atau Idul Fitri. Sikap dan nilai-nilai tersebut di atas diimplementasikan juga oleh masyarakat Jawa terhadap suku bangsa yang lain di Suriname, namun tidak seintensif terhadap masyarakat Jawa. Di samping itu kegiatan solidaritas Jawa di Suriname ditunjukkan dengan pergelaran-pergelaran seni dan adat-istiadat lainnya.

5). Penerapan sikap dan nilai-nilai kearifan lokal Jawa yang berorientasi pada prinsip rukun dan hormat tersebut cukup efektif untuk menyelesaikan suatu konflik, perselisihan, atau pertikaian masyarakat Suriname yang demikian beragam. Orang Jawa di Suriname yang terkenal di sana lembut, sopan, pekarangan rumahnya bersih dan rapi menjadi keteladanan bagi masyartakat yang lain (ing ngarsa sung tuladha); orang Jawa menunjukkan sikap ambil inisiatif, kreativitas, dan motivasi di tengah-tengah masyarakat untuk mewujudkan cita-cita yang disepakati, disadari, dan dipahami bersama (ing madya mangun karsa); orang Jawa, sebagai pemimpin memberikan perhatian, daya kekuatan, dan dorongan spiritual agar anggota masyarakat tumbuh semangatnya mengembangkan kreativitasnya untuk mengerjakan tugas dan kewajiban bersama yang telah dicita-citaklan (tut wuri handayani).

\section{DAFTAR REFERENSI}

Abdullah Ciptoprawiro. 1986. Filsafat Jawa. Jakarta: Balai Pustaka.

Bidang Penerangan KBRI Paramaribo. 2003. Keterangan Dasar Suriname. Paramaribo: Kedutaan Besar Republik Indonesia Paramaribo.

Berg, C.C. 1974. Penulisan Sejarah Jawa. Terjemahan S. Gunawan. Jakarta: Bhratara.

Budiono Herusatoto. 2011. Mitologi Jawa. Depok: Oncor Semesta Ilmu

Frans Magnis Suseno. 1985. Etika Jawa. Jakarta: PT Gramedia.

Hazim Amir. 1991. Nilai-Nilai Etis dalam Wayang. Jakarta: Pustaka Sinar Harapan.

KBRI Paramaribo. 2003. Keterangan Dasar Suriname. Paramaribo: KBRI Paramaribo

Moedjanto. 1987. Konsep Kekuasaan Jawa: penerapannya oleh Raja-Raja Mataram. Yogyakarta: Kanisius.

Mulder, Niels. 1984. Kebatinan dan Hidup Sehari-Hari Orang Jawa: Kelangsungan dan Perubahan Kulturil. Jakarta: PT Gramedia. . 1985. Pribadi dan Masyarakat di Jawa. Jakarta: Sinar Harapan

Mulyana. 2006. Spiritualisme Jawa: Meraba Dimensi dan Pergulatan Religiusitas Orang Jawa. Jurnal Kebudayaan Jawa Kejawen. Vol. 1 No.2, 1-13

(Penyunting). 2005. Demokrasi dalam Budaya Lokal. Sleman Yogyakarta: Tiara Wacana

Pandam Guritno. 1988. Wayang Kepribadian Indonesia dan Pancasila. Jakarta: UI Press.

Peursen, C.A. van. 1989. Strategi kebudayaan. Yogyakarta: Kanisius. 
Poerbatjaraka. 1952. Kapustakan Djawi. Jakarta: Djambatan.

R. Soekmono. 1991. Pengantar Sejarah Kebudayaan Indonesia Jilid 1-3. Yogyakarta: Kanisisus.

Siswoharsojo. 1957. Pakem Makutha Rama. Yogyakarta: Pesat.

Soemarsaid Moertono. 1985. Negara dan Usaha Bina negara di Jawa Masa Lampau. Jakarta: Yayasan Obor Indonesia.

Sujamto. 1991. Sabda Pandhita ratu. Semarang Dahara Prize.

Sunoto. 1987. Menuju Filsafat Indonesia. Yogyakarta: PT Hanindita.

Suparjo. 1941. Ruwatan: Ingkang Karuwat Tiyang Adang Karubuhan Dandang. Jakarta: Ruang Naskah FIB-UI.

Thomas Wiyasa Bratawijaya. 1988. Upacara Tradisional Masyarakat Jawa. Jakarta: Pustaka Sinar Harapan.

Zaairul Haq. 2013. Ajaran Makrifat: Penuntun Jiwa Yang Jawa. Bantul Yogyakarta: Kreasi Wacana

Informan:

Drs. Suparmin Sunjoyo, mantan Duta Besar LBPP Indonesia untuk Suriname tahun 2002-2006 